\title{
北米スポーツマネジメント学会 2014 年度大会 \\ The North American Society for Sport Management Conference 2014
}

\author{
浅田瑛（フロリダ大学大学院） \\ 隅野美砂輝（鹿屋体育大学）
}

\begin{abstract}
今年度で 29 回目となる 2014 年北米スポーツマネジメント学会 (North American Society for Sport Management：以下「NASSM」と略す）が、2014 年 5 月 27 日から 5 月 31 日にかけてペン シルバニア州ピッツバーグで開催された。本大会には世界各国から総勢 573 人の研究者、実務家、 そして学生が参加した。なお、NASSM の発表によれば今回の参加者数は過去最多であった。研究 発表の応募総数は 487 件、採択数は 302 件であり（採択率 $62 \%$ ）、昨年よりやや採択率の高い大 会であった（2013 年度：採択数 311 件、採択率 $58.8 \%$ )。
\end{abstract}

\section{研究分野別の動向}

表 1 に過去 3 年間の研究分野別発表数の動向をまとめた。過去 2 年と同様、今年度もマーケティ ングが最も発表数の多い研究分野となった。一方で、昨年まで 2 番目に発表数の多い分野であっ たマネジメントノリーダーシップが 3 番目に、3 番目に多かった社会・文化的側面が 2 番目にそ れぞれ順位が入れ替わった。社会・文化的側面に関する研究発表は近年増加傾向にあり、発表件数 が 15 件であった 5 年前の 2009 年度大会と比較すると、その数は 3 倍に達している。

表 1 過去 3 年間の研究分野別発表数の増減

\begin{tabular}{lccc}
\hline \multicolumn{1}{c}{ 分野 } & 2012 & 2013 & 2014 \\
\hline マーケティング (Marketing) & $73(23.2 \%)$ & $83(27.3 \%)$ & $81(27.2 \%)$ \\
社会・文化的側面 (Socio-cultural) & $42(13.3 \%)$ & $32(10.5 \%)$ & $45(15.1 \%)$ \\
マネジメントノリーダーシップ (Management/leadership) & $44(14.0 \%)$ & $48(15.8 \%)$ & $31(10.4 \%)$ \\
コミュニケーション (Communication) & $17(5.4 \%)$ & $18(5.9 \%)$ & $25(8.4 \%)$ \\
組織論/組織文化 (Organizational Theory/culture) & $24(7.6 \%)$ & $19(6.3 \%)$ & $22(7.4 \%)$ \\
人材の多様性 (Diversity) & $16(5.1 \%)$ & $20(6.6 \%)$ & $17(5.7 \%)$ \\
ガバナンス (Governance) & $9(2.9 \%)$ & $13(4.3 \%)$ & $16(5.4 \%)$ \\
教授法 (Teaching) & $20(6.3 \%)$ & $12(3.9 \%)$ & $13(4.4 \%)$ \\
経済学 (Economics) & $17(5.4 \%)$ & $18(5.9 \%)$ & $10(3.4 \%)$ \\
専門的職業準備 (Professional preparation) & $16(5.1 \%)$ & $12(3.9 \%)$ & $10(3.4 \%)$ \\
スポーツ・ツーリズム (Sport tourism) & $9(2.9 \%)$ & $8(2.6 \%)$ & $7(2.3 \%)$ \\
法的問題 (Legal aspects) & $11(3.5 \%)$ & $8(2.6 \%)$ & $7(2.3 \%)$ \\
研究法 (Research/statistical methodology) & $8(2.5 \%)$ & $6(2.0 \%)$ & $6(2.0 \%)$ \\
金融論 (Finance) & $5(1.6 \%)$ & $5(1.6 \%)$ & $5(1.7 \%)$ \\
倫理学 (Ethics) & $4(1.3 \%)$ & $2(0.7 \%)$ & $3(1.0 \%)$ \\
\hline 合計 & 315 & 304 & 298
\end{tabular}


これらの動向を受けて、トロイ大学教授のパキアナサン・チェラデュライ氏にお話を伺ったとこ ろ、「これまで観戦型スポーツに学術的興味を集めてきた NASSM が、参加型スポーツやその他の 領域に目を向けている表れであり、個人的には好意的に捉えている。なぜならスポーツ産業はとて も大きく、プロスポーツや大学スポーツだけではないからである」と語ってくれた（P. Chelladurai, personal communication, May 30, 2014)。以下では、発表件数が上位であったマーケティングと社会・ 文化的側面、そして下位ではあるが興味深い研究が発表された教授法と専門的職業準備の 4 分野 について詳しく述べたい。

\section{マーケティング}

本大会で発表された 81 件のマーケティング研究の内、17 件 (21\%) がスポンサーシップに関 する研究であった。スポンサーシップ研究はこれまでの NASSM でも多く発表されてきたが、本大 会ではとりわけユニークな研究発表が目を引いた。例えば、Jensen et al. (2014) はスポーツ観戦者 が観戦中にスマートフォンやタブレット端末を利用する Second Screen Activity という観戦者行動に 着目し、その行動がテレビ観戦中の人々のスポンサー認知および想起に与える負の影響を研究した。 また Walsh et al. (2014) は、人の眼の動きを追跡する Eye Tracking System を用いたスポンサーシッ プ研究を発表した。彼らは、スポンサーシップの効果を測定するためにブランド認知やブランド想 起を従属変数に設定することへの疑問を提示し、Eye Tracking System によって測定できる視覚的注 意（Visual Attention）およびブランドに対する態度を用いることの優位性を説いた。

研究デザインに目を向けてみると、調査研究が 44 件で最も多く、その内約半数の 20 件の研究 が構造方程式モデリング分析（Structural Equation Model: SEM）を用いた実証的研究であった。そ の他には、質的研究が 13 件、実験研究が 11 件、そして概念研究が 5 件と続いた。

\section{社会・文化的側面}

社会・文化的側面に関する研究は、昨年から発表件数が最も増加した研究分野である。また、本 大会で発表された 45 件の研究の内、 24 件（53\%）が参加型スポーツに関するものである点はチェ ラデュライ氏が指摘した NASSM の傾向にも重なる（観戦型スポーツに関する発表は 11 件)。し たがって、量的にも内容的にも本大会の特徴を色濃く映し出した研究分野と言えるだろう。同分野 で最も多く発表された研究は、スポーツによる地域発展に関するものであった。その中でも SportFor-Development に関する発表が増加しているのが印象的であった。同テーマは昨年度の NASSM で注目を集め始めている研究領域として紹介されたが、今年度は 6 件の研究発表が同テーマに関 するものであった。例えば、Arnold and Spence（2014）は、南アフリカで実施された “FFSA Sport for Development Programs”という取り組みに関する研究発表を行った。同プログラムは、南アフリ カフットボール連盟が展開するもので、サッカーを通じて「人々の生活技能の習得」や「犯罪の減 少」といった社会的影響を与えることを目的にしている。同プログラムのように、スポーツと直接 的な関係が薄い社会的側面に影響を与えようとすることが Sport-For-Development ではしばしばあ り、その効果が不明瞭なことが指摘されてきた (Levermore, 2008)。そこで Arnold and Spence (2014) は、同プログラムの効果を測定するために、「開催地域のニーズがどのように満たされたか」、「ど のような社会的影響を与えたか」、そして「主催者の信念が、プログラムの展開にどのように影響 したか」という点に注目して、主催者と参加者を対象にしたインタビュー調査を実施した。その結果、 
主催者が社会の広い範囲に影響を与えようと試みているのに対して、参加者が求めているのは「プ ログラムの競技性」であることがわかった。この結果は、プログラム主催者の目的と参加者のニー ズの間に違いがあることを明らかにしたものと解釈できる。一方で、この研究によって同プログラ ムの効果が正しく測定されたかについては批判がなされるべきであろう。なぜなら、同研究でイン タビューを受けたプログラム参加者は、プログラム参加中もしくは参加直後にプログラム実施現場 にてその評価を行っており、そのような状況下での評価が社会的な影響よりもプログラム自体の評 価になるというのは半ば当然であるからだ。Sport-For-Developmentのような新しい取り組みに対し て学術的な興味が集まり、その効果が科学的に測定されるのは重要な傾向であるが、研究結果の妥 当性と信頼性を確立するためには、データ収集方法を含めた研究デザインに関しても更なる議論が 望まれる。

\section{教授法および専門的職業準備}

近年、我が国において大学教育の質や学士取得者の能力が問われているように、北米においても 学生が専門性の高い知識や技能を十分に身につけられるよう教育されているかが盛んに議論されて いる。このようなテーマに関して、本大会では、教授法（13 件）と専門的職業準備（10 件）の分 野において研究発表が行われた。Popp et al. (2014) は、スポーツマネジメントの現役大学院生と 修了生を対象に大学院プログラムに対する満足度を調査した。調査結果によれば、スポーツマネジ メントの修士課程へ進学したことに対する満足度は 5.12、プログラムに対する満足度は 4.65 (い ずれも 6 段階評価）と比較的高い満足度が得られていた。また、プログラム内で最も有益だった と回答された科目は、「最新のトピック」「スポーツと社会」「スポーツマーケティング」「スポー ツ倫理」であった。反対に、有益ではなかった科目として「統計」、国際スポーツ」「女性スポーツ」、 「研究法」が挙げられた。そして、大学院プログラムにおいて強化されるべき要素として、基礎的 なビジネス科目を求める回答が多く見られた。またDeLuca et al. (2014) は、学生が専門職に就け るだけの準備をどの程度行えているかがカリキュラム開発の出発点であるという考えのもと、学生 の能力に関する自己評価を分析した。その結果、学生はインターンシップや就職を迎える時点で、 実践的および応用的な職業的能力に対する不安を抱えていることが明らかとなった。この研究結果 は、現行のプログラムに実践的な経験を積める科目が不足していることを示唆するものであり、よ り導入的な実習の機会について検討されるべきであると提言された。一方、Smith (2014) は、スポー ツマネジメントプログラムに携わる大学教員の研究業績に注目し、スポーツマネジメントの今後に ついて独自の観点から意見を述べた。彼は、NASSM のウェブサイトに掲載されているスポーツマ ネジメントプログラムを提供する大学（計 438 校）の教員を対象に、彼らの研究業績（学術論文 および学会発表)を定量的に分析した。その結果、ほとんどの研究業績がスポーツもしくはレジャー 関連の領域に留まっていることが明らかとなった。学問領域の信頼性を高める上で学際的研究が果 たす役割の重要性はこれまでも指摘されており（Chalip, 2006)、Smith (2014) は関連分野や親学 問においても研究業績を積むことがスポーツマネジメントプログラムの信頼性をより高めるために 必要であると主張した。

\section{基調講演・シンポジウム}

基調講演は、NBA クリーブランド・キャバリアーズの CEO である Len Komoroski 氏により行わ 
れた。近年北米では、大規模な都市再開発計画にスポーツ施設の建設がしばしば組み込まれている。 講演では、氏によってそのような事例が多数紹介され、プロスポーツチームが地域発展に期待され る役割が大きくなっていると説明された。また講演の後半部分では、スポーツの現場で働く実務家 として、スポーツマネジメントプログラムには優秀で専門性のある人材を輩出する使命があると指 摘し、最新のトピックやトレンドを踏まえた教育がより一層なされることが期待されると述べた。 一方で、“Creating Service Learning Experiences in Sport Management”と題されたシンポジウムでは、 4 名のパネリストから各大学で実施されているスポーツマネジメント実習が紹介され、そのプロセ スや効果、問題点などについて議論が展開された。アメリカのスポーツマネジメントプログラムで は 400 時間の実習を卒業の条件としている大学が多く、同プログラムにおいて極めて重要な要素 となっている。パネリストからは、実習を経験した学生が、学習意欲の向上、市民意識の芽生え、 一般的および専門的技能の獲得などを達成していることが報告された。また、実習前に学生の犯罪 歴をFBI のシステムを用いて審査をしている大学の事例も報告された。青少年や女性、高齢者に 対するサービスを提供するような実習を行うことの多いスポーツマネジメントプログラムでは、こ のようなリスクマネジメントもシステムとして組み込まれる必要があると指摘された。

\section{おわりに}

本大会では、過去数年から研究発表の傾向が大きく変わった。近年の NASSM ではソーシャルネッ トワーキングサイトなどのニューメディアが注目を集めてきたが、本大会ではスポーツの社会・文 化的な側面に関する研究発表が目立った。他の学問領域やスポーツ産業界の動向を強く反映するス ポーツマネジメント研究において、その研究内容は多様であり研究動向は変動しやすい。したがっ て、移り変わる研究動向に注意を払うことと共に、自らの研究活動がその動向を追うだけのものに ならぬよう心掛けることも重要である。

また、本報告では詳しく紹介できなかったが、本大会ではティーチング・フェアや博士課程の大 学院生向けのシンポジウム、そして学科長・学部長などの管理教職員向けのシンポジウムまで、興

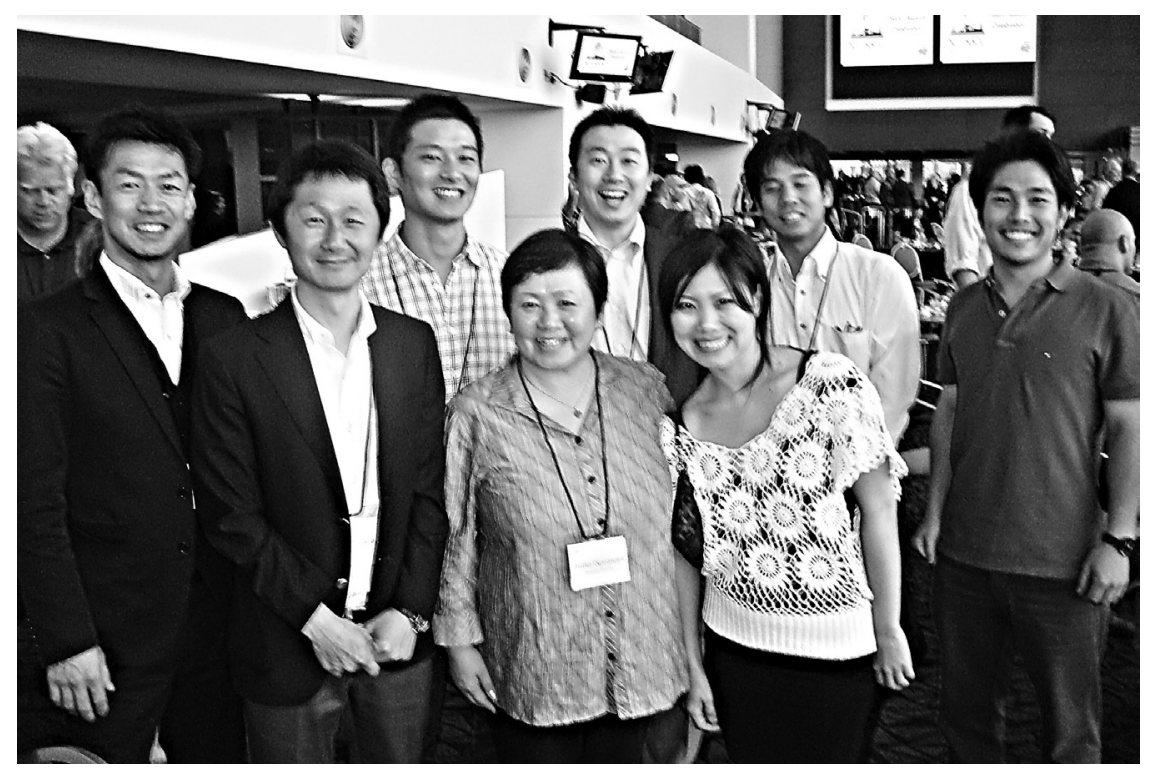

写真 日本人参加者で記念撮影 
味深いプログラムが多数催されたことも付記しておきたい。このように、学術的な研究発表だけで なく、教職員の育成やカリキュラム開発に繋がるようなイベントも充実しているのが NASSM の特 徵である。学会大会の開催期間が日本の大学の授業期間と重なっており参加は容易ではないが、日 本からもより多くの研究者、大学院生、そして学生が参加され、有益な情報共有や情報発信がなさ れることを期待したい。

来年度の NASSM は2015 年 6 月 2 日より 6 日まで、“Knowledge, Passion, Community: Driving Sport Forward”をテーマにカナダのオンタリオ州オタワで開催される。開催地のオタワは、この学 会大会期間後に開幕する FIFA Women's World Cup Canada 2015 の会場のひとつでもあり、特別パッ ケージチケットの提供も予定されているようである。その他、詳細は学会ウェブサイトをご参照い ただきたい（www.nassm.com/NASSM2015）。

\section{【文献】}

Arnold, C. and Spence, K. (2014) Evaluation in Sport for Development: A case Study of the Gansbaai Project, Football Foundation of South Africa, from a Critical Perspective. 20-minute oral presentation at the 29th North American Society for Sport Management Conference, Pittsburgh, PA, USA.

Chalip, L. (2006) Toward a distinctive sport management discipline. Journal of Sport Management, 20: 1-21.

DeLuca, J. R., Braunstein-Minkove, J. R., and Glenn, K. A. (2014) Evaluating Internships: Effectively Adapting Curricula and Harnessing Internal and External Resources to Address Industry-Specific Needs. 20-minute oral presentation at the 29th North American Society for Sport Management Conference, Pittsburgh, PA, USA.

Jensen, J. A., Walsh, P., Cobbs, J. B., and Turner, B. A. (2014) Assessing the Impact of Second Screen Activity During Television Broadcasts on Sponsor Brand Awareness. 20-minute oral presentation at the 29th North American Society for Sport Management Conference, Pittsburgh, PA, USA.

Levermore, R. (2008) Sport a new engine of development? Progress in development studies, 8(2): 183-190.

Pent, A., Crowley, C., Pitts, B., Johnson, W., Anderson, D. L., and Butler, N. (2014) Creating Service Learning Experiences in Sport Management. 60-minute symposium at the 29th North American Society for Sport Management Conference, Pittsburgh, PA, USA.

Popp, N., Weight, E., Morse, A., and Baker, A. (2014) Assessing Stakeholder Satisfaction of Graduate Sport Management Programs. 20-minute oral presentation at the 29th North American Society for Sport Management Conference, Pittsburgh, PA, USA.

Smith, J. (2014) Enhancing the Credibility of Sport Management Programs: An Assessment of Publications, Presentations and Research Interests. 20-minute oral presentation at the 29th North American Society for Sport Management Conference, Pittsburgh, PA, USA.

Walsh, D. W., Kim, K., and Bowers, M. (2014) Understanding the Effects of Sponsorship Disclosure on Television Consumers as a Function of Visual Attention: An Eye Tracking Technological Method. 20-minute oral presentation at the 29th North American Society for Sport Management Conference, Pittsburgh, PA, USA. 